\title{
Komunikasi dan Pola Asuh Anak Balita - Remaja dalam Keluarga Betawi Jakarta dan Bekasi
}

\author{
Afrina Sari \\ Magister Ilmu Komunikasi Universitas Budi Luhur Jalan Salemba Ciledug Nomor 34-36Z \\ Telephone (021) 5686666 Fax (021) 5633719 Jakarta, \\ Email: afrina.sari68@yahoo.co.id
}

\begin{abstract}
This research aims to test the significant differences the use of family communication and the pattern of childcare toddlers and teenagers in families living in the Kampung Tugu in north Jakarta, Kampung Condet in East Jakarta and Ujung Harapan in bekasi. This study using quantitative methods of correlational. The results of research shows that the communication in childcare on the community in Kampung Tugu of north Jakarta, more affected from ways obtained from earlier the generations. The average betawi people in their religious pillar of the nazarenes, some are muslim. For people who follow the Islamic religion, they to develop a pattern of parenting in the family in Islamic way. The Betawi Community of Kampung Condet in East Jakarta, further develop ways a family tradition which are influenced by arab cultures ways. So they develop more into islamic ways. Also betawi people on Kampung Ujung Harapan in Bekasi, almost the entire community on Kampung Ujung Harapan Bekasi are moeslim. So that childcare more patterns dominated by islamic ways which were inherited from earlier generations. A pattern to the consistence of parenting in educating if compared between toddlers and teenagers, the community in Kampung Tugu more dominant educate young teen, while the Kampung Condet and Kampung Ujung Harapan directing consistency educate in toddlers and teenagers.
\end{abstract}

Keyword: parenting, communication, people, Betawi Culture

\begin{abstract}
Abstrak
Penelitian ini bertujuan untuk menguji perbedaan signifikan penggunaan komunikasi keluarga dan pola pengasuhan anak balita dan remaja pada keluarga yang tinggal di Kampung Tugu Jakarta Utara, Kampung Condet Jakarta Timur dan Kampung Ujung Harapan Bekasi. Penelitian ini menggunakan metode kuantitatif khususnya korelasional. Hasil penelitian menunjukkan bahwa pola komunikasi dalam pengasuhan anak pada masyarakat di Kampung Tugu Jakarta Utara, lebih dipengaruhi dari cara-cara yang didapat dari generasi sebelumnya. Rata-rata Masyarakat Betawi di Kampung Tugu beragama Nasrani, sebagian beragama Islam. Bagi Masyarakat yang beragama Islam mengikuti caracara Islam dalam mengembangkan pola pengasuhan pada keluarga. Masyarakat Betawi di Kampung Condet Jakarta Timur, lebih mengembangkan cara-cara tradisi keluarga yang dipengaruhi oleh cara-cara Budaya Arab. Sehingga lebih mengembangkan cara-cara kehidupan islami. Begitu juga Masyarakat Betawi di Kampung Ujung Harapan Bekasi, hampir seluruh masyarakat Ujung Harapan Bekasi adalah Islam. Sehingga pola-pola pengasuhan anak lebih didominasi dengan cara-cara Islam yang diwarisi dari generasi sebelumnya. Pola pengasuhan dengan konsistensi dalam mendidik jika dibandingkan antara balita dan remaja, masyarakat di Kampung Tugu lebih dominan mendidik anak remaja, sedangkan masyarakat Kampung Condet dan kampung Ujung Harapan mengarahkan konsistensi mendidik pada balita dan remaja.
\end{abstract}

Kata kunci: pola pengasuhan, komunikasi, masyarakat, Budaya Betawi 


\section{Pendahuluan}

Ke ragam a $\mathrm{n}$ buday y a $\mathrm{g}$ mempengaruhi masyarakat Budaya Betawi baik yang tinggal di Jakarta dan Bekasi, berakibat kepada akan memunculkan banyak cara berkomunikasi dalam pengasuhan terhadap anak dan remaja dalam lingkungan keluarga. Sehingga akan memunculkan banyak polapola pengasuhan dan pola-pola berkomunikasi dalam keluarga. Selain keragaman budaya yang mempengaruhi budaya Betawi, kepercayaan kepada Tuhan yang Maha Esa juga mempunyai peran penting dalam mempengaruhi masyarakat budaya Betawi dalam mentransformasikan nilai-nilai budaya kepada anak dan remaja pada keluarga Betawi Jakarta dan Bekasi. Sehingga akan memuncul beragam pola transformasi nilai-nilai yang dilakukan keluarga Betawi Jakarta dan Bekasi.

Konsep komunikasi dan pola pengasuhan anak usia balita dan remaja dalam keluarga Betawi Jakarta dan Bekasi meliputi cara orangtua melakukan interaksi dengan anak balita dan remaja yang mereka miliki. Cara ini akan bisa muncul dengan bermacam ragam. Sehingga dampaknya adalah pada kepribadian anak dikala berinteraksi dengan orang lain di luar anggota keluarga. Penggunaan bahasa yang disertai logat, dialek dan tekanan nada akan mempengaruhi cara bicara anak saat bermain dengan teman sebayanya. Hal lain yang menjadi perhatian dalam penelitian ini adalah penggunaan komunikasi nonverbal dalam setiap interaksi dengan anak usia balita dan remaja. Baumrind dalam Irmawati (2004) menganggap bahwa pola pengasuhan tertentu dalam keluarga akan memberi pengaruh terhadap perkembangan kepribadian anak.

Berdasarkan uraian tersebut diatas, maka permasalahan pada penelitian ini adalah bagaimana perbedaan pola komunikasi yang dilakukan keluarga Betawi Jakarta dan Betawi Bekasi terhadap anak usia balita dan remaja,yang dibagi dalam tiga lokasi yaitu; Kampung Condet Jakarta Timur, Kampung Tugu
Jakarta Utara dan Kampung Ujung Harapan Bekasi. Tujuan penelitian ini adalah menguji perbedaan signifikan penggunaan komunikasi keluarga dan pola pengasuhan anak Balita dan remaja pada keluarga yang tinggal di Kampung Tugu Jakarta Utara, Kampung Condet Jakarta Timur dan Kampung Ujung $\mathrm{H}$ a $\mathrm{r}$ a $\mathrm{p}$ a $\quad$ B e k a $\mathrm{s}$.

Subjek penelitian ini berasal dari masyarakat Betawi baik yang tinggal di Jakarta maupun yang tinggal di Bekasi beragama Islam. Sebagian dari masyarakat tersebut ada yang memiliki kepercayaan kepada dunia gaib atau tahayul-tahayul. Akibatnya ada pencampuran ajaran Islam dengan upacara-upacara tradisional yang berkaitan dengan daur hidup. Terutama pada komunitas tertentu, selain percaya pada ajaran agamanya, mereka juga mempunyai kepercayaan terhadap hal-hal yang dianggap gaib (super natural), yaitu percaya kepada adanya hal-hal yang berada diluar batas kemampuan manusia (Supriatna, 2008:607). Tatanan sosial orang Betawi lebih didasarkan pada senioritas umur, artinya orang muda menghormati orang yang lebih tua. Hal ini dapat diamati dalam kehidupan sehari-hari melalui komunikasi interpersonal. Pengertian Komunikasi interpersonal adalah komunikasi yang dilakukan oleh dua orang individu atau lebih dalam konteks kepentingan masing-masing individu. Komunikasi interpersonal antara orangtua dengan anak balita dan remaja pada masyarakat Betawi, dapat diperhatikan pada saat mereka melakukan aktivitas bersama. Komunikasi interpersonal terkadang tidak efektif apabila tidak ada tujuan yang jelas dalam melakukan proses komunikasi. Menurut DeVito (2007:38) faktor yang dapat mempengaruhi komunikasi interpersonal agar menjadi lebih efektif adalah: a) Keterbukaan: Sifat keterbukaan menunjukkan paling tidak dua aspek tentang komunikasi interpersonal. Aspek pertama yaitu, bahwa kita harus terbuka pada orangorang yang berinteraksi dengan kita. Dari sini orang lain akan mengetahui pendapat, pikiran dan gagasan kita. Sehingga komunikasi akan mudah dilakukan. Aspek kedua dari keterbukaan merujuk pada 
kemauan kita untuk memberikan tanggapan terhadap orang lain dengan jujur dan terus terang segala sesuatu yang dikatakannya, demikian sebaliknya b) Empati: Empati adalah kemampuan seseorang untuk menempatkan dirinya pada peranan atau posisi orang lain. Mungkin yang paling sulit dari faktor komunikasi adalah kemampuan untuk berempati terhadap pengalaman orang lain. Karena dalam empati, seseorang tidak melakukan penilaian terhadap perilaku orang lain tetapi sebaliknya harus dapat mengetahui perasaan, kesukaan, nilai, sikap dan perilaku orang lain. c) Perilaku Sportif: Komunikasi interpersonal akan efektif bila dalam diri seseorang ada perilaku sportif, artinya seseorang dalam menghadapi suatu masalah tidak bersikap bertahan (defensif).

Menurut DeVito (2007:58), keterbukaan dan empati tidak dapat berlangsung dalam suasana yang tidak sportif. Menurut Kohlberg dalam Crain (2007:107) tahapan moral ini berhubungan dengan kemajuan kognitif dan tingkah laku moral.

Menurut Piaget dalam Crain (2007 :209), manusia tumbuh, beradaptasi dan berubah melalui perkembangan fisik, perkembangan kepribadian, perkembangan sosio-emosional, dan perkembangan kognitif. Perkembangan kognitif sebagian besar bergantung kepada seberapa jauh anak memanipulasi dan aktif dalam berinteraksi dengan lingkungannya. Ada tiga aspek perkembangan intelektual yaitu struktur, isi dan fungsi. Struktur atau skemata merupakan organisasi mental tingkat tinggi yang terbentuk pada individu waktu ia berinteraksi dengan lingkungannya. Isi merupakan pola perilaku khas anak yang tercermin pada responsnya terhadap berbagai masalah atau situasi yang dihadapi. Sedangkan fungsi adalah cara yang digunakan organisme untuk membuat kemajuankemajuan intelektual. Fungsi itu sendiri terdiri dari organisasi dan adaptasi.

Piaget dalam Crain (2007 : 221) menjelaskan bahwa perkembangan anak merupakan segala perubahan yang terjadi pada usia anak, yaitu pada masa (1) Infancy toddlerhood (usia 0-3 tahun),
(2) Early childhood (usia >3-6 tahun) dan (3) Middle childhood (usia >6-11 tahun). Perubahan yang terjadi pada diri anak tersebut meliputi perubahan pada aspek berikut: fisik (motorik), emosi, kognitif dan psikososial.

Keluarga merupakan sistem sosialisasi bagi anak, dimana ia mengalami pola disiplin dan tingkah laku afektif.

Walaupun seorang anak telah mencapai masa remaja dimana keluarga tidak lagi merupakan pengaruh tunggal bagi perkembangan mereka, keluarga tetap merupakan dukungan yang sangat diperlukan bagi perkembangan kepribadian remaja tersebut. Dengan demikian peran orangtua sangat dibutuhkan, terutama karena bertanggung jawab menciptakan sistem sosialisasi yang baik dan sehat bagi perkembangan moral remaja. Remaja sedang tumbuh dan berkembang, karena itu mereka memerlukan kehadiran orang dewasa yang mampu memahami dan memperlakukannya secara bijaksana (Hastuti, 2008 :52).

Interaksi sosial awal terjadi di dalam kelompok keluarga. Anak belajar dari orangtua, saudara kandung, dan anggota keluarga lain apa yang dianggap benar dan salah oleh kelompok sosial tersebut. Dari penolakan sosial atau hukuman bagi perilaku yang salah, dan dari penerimaan sosial atau penghargaan bagi perilaku yang benar, anak memperoleh motivasi yang diperlukan untuk mengikuti standar perilaku yang ditetapkan anggota keluarga (Gunarsa, 2004 :19).

Perhatian Utama dalam penelitian ini adalah komunikasi keluarga, pola pengasuhan, model transformasi nilai-nilai budaya pada Budaya Betawi. Penelitian ini dipetakan berdasarkan pemilihan lokasi penelitian pada Kampung Tugu Jakarta Utara, Kampung Condet Jakarta Timur, dan Kampung Ujung harapan Bekasi.

Dalam penelitian ini variabel yang diteliti adalah: Komunikasi interpersonal orangtua kepada Anak balita dan Remaja yang meliputi:

1) Sikap keterbukaan, 2) Sikap empati 3) perilaku sportif. Dan peubah antara yang diamati meliputi 1) Komunikasi verbal: 


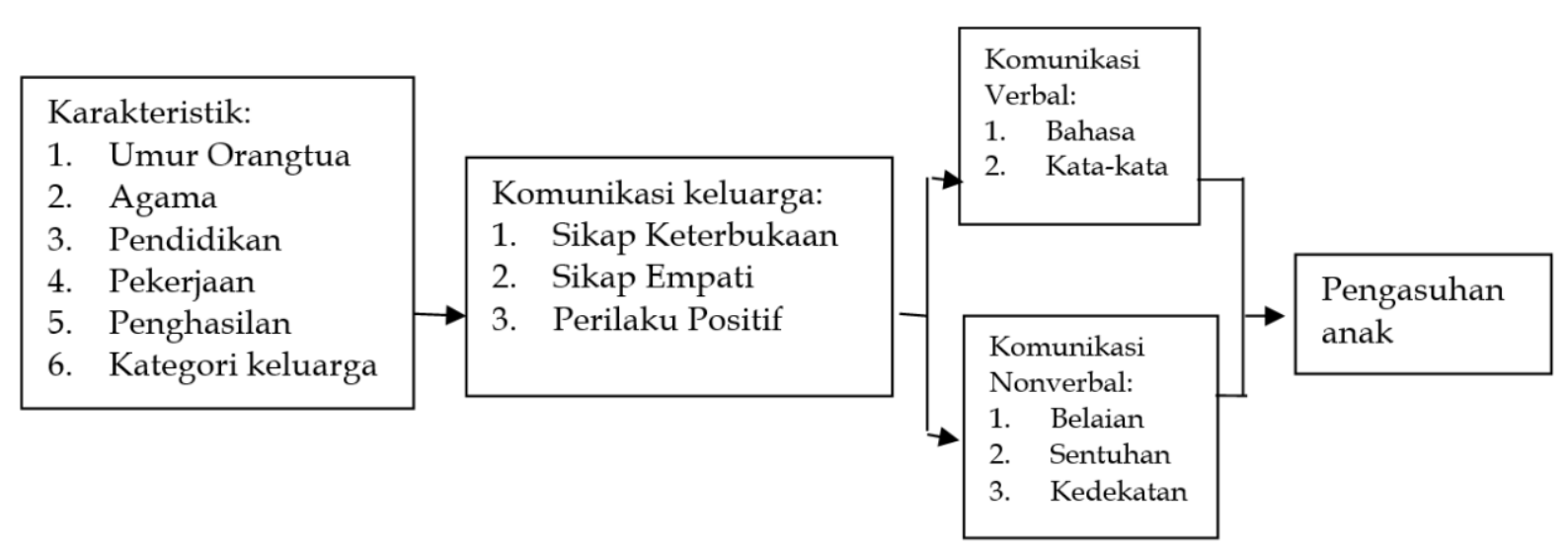

Gambar 1. Kerangka penelitian Komunikasi Keluarga,

Pola Pengasuhan Anak Balita dan remaja pada Budaya Betawi (Sumber data Primer tahun 2013)

(bahasa, penggunaan kata-kata) dan 2) Komunikasi nonverbal: (belaian, sentuhan, kedekatan). Serta peubah terikat yaitu Pengasuhan Anak. Untuk lebih jelas dapat digambarkan pada gambar diatas

Hipotesis Penelitian ini yaitu terdapat perbedaan signifikan antara pola komunikasi yang dilakukan keluarga Betawi Jakarta dan Betawi Bekasi terhadap anak usia balita dan remaja, yang dibagi dalam tiga lokasi yaitu; kampung Condet Jakarta Timur, Kampung Tugu Jakarta Utara dan Kampung Ujung Harapan Bekasi.

\section{Metode Penelitian}

Penelitian ini menggunakan Desain kuantitatif Deskriptif Korelasional. Pemilihan tempat dalam penelitian ini dilakukan secara purposive yaitu Kampung Ujung Harapan Bekasi, Kampung Tugu Jakarta Utara, Kampung Condet Jakarta Timur, dengan pertimbangan bahwa Kampung Ujung Harapan, Kampung Tugu dan Kampung Condet merupakan kampung yang masih memegang teguh nilai-nilai Budaya Betawi.

Populasi penelitian adalah penduduk yang tinggal dalam suatu wilayah (Creswell 2002:112) dalam penelitian ini yaitu penduduk yang merupakan masyarakat Betawi di Jakarta dan penduduk Betawi di Bekasi yang memiliki anak usia 3-5 tahun dan memiliki anak remaja berusia 11-17 tahun yang di bagi dalam 2 kategori yaitu keluarga miskin dan keluarga mampu. Sampel dari penelitian ini adalah orangtua baik lakilaki ataupun perempuan.
Pengumpulan data primer untuk penelitian ini dilakukan dengan menggunakan kuisioner yang di bagi dalam tiga bagian yaitu: bagian pertama berisikan tentang karakteristik keluarga dan anggota keluarga Betawi di tiga lokasi. Bagian kedua, berisikan tentang pola-pola komunikasi antara individu dalam keluarga pada keluarga Betawi di tiga wilayah penelitian. Bagian ketiga, berisikan bentuk-bentuk pengasuhan dan aktivitas pengasuhan yang dilakukan oleh keluarga Betawi di tiga lokasi penelitian. Data kualitatif untuk mendalami materi ataupun pengolahan data primer dilakukan dengan teknik wawancara mendalam dan observasi (Arikunto 2006:86).

Analisis data untuk data tahun pertama dilakukan dengan mengunakan analisis uji statistik Rank Spearman untuk melihat rangking pola komunikasi yang digunakan keluarga dalam pengasuhan anak dan remaja di keluarga Betawi. Juga menggunakan Analisis Wicolson untuk melihat perbedaan pola yang digunakan orangtua dalam pengasuhan anak balita dan remaja di tiga lokasi penelitian. Data penelitian tahun pertama di analisis menggunakan analisis statistik software SPSS version.18.

\section{Hasil Penelitian dan Pembahasan}

\section{Karakteristik Responden}

Karakteristik personal responden meliputi: (1) usia (2) agama, (3) pendidikan, (4) pekerjaan. (5) penghasilan. Untuk menunjukkan nilai uji Korelasi dengan uji Rank Spearman disajikan dalam grafik 1 berikut: 


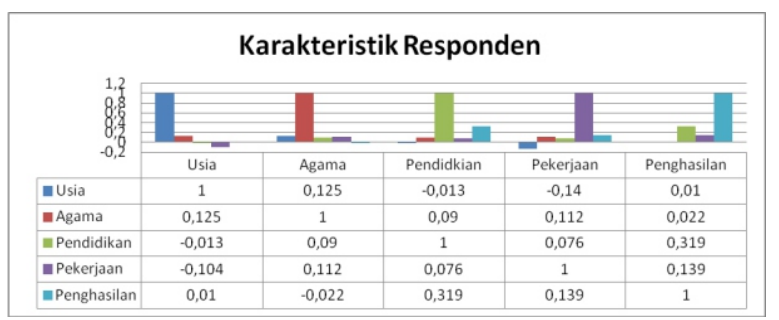

Grafik 1. Karakteristik Responden

Berdasarkan Grafik 1, maka dapat dijelaskan bahwa nilai korelasi usia menunjukkan nilai 1,000, nilai korelasi agama 0,125 , nilai korelasi pendidikan -0,013, nilai korelasi pekerjaan 0,14 , dan nilai korelasi penghasilan 0,01 . Nilai korelasi yang berhubungan secara signifikan adalah penghasilan dengan pendidikan nilai korelasi $0,319(\mathrm{p}<0.05)$.

Pekerjaan dengan penghasilan juga mempunyai hubungan secara signifikan dengan nilai korelasi $0,139(p<0,05)$. Artinya pendidikan dan pekerjaan menentukan penghasilan seseorang, terutama dalam penelitian ini menunjukkan bahwa tingkat penghasilan ditentukan oleh pendidikan dan pekerjaan yang dilakukan.

\section{Karakteristik Keluarga}

Karakteristik keluarga meliputi: (1) Kategori keluarga (2) Status rumah, (3) Belanja Pakaian (4) Kendaraan yang di miliki. Untuk menunjukkan nilai Uji Korelasi dengan Uji Rank Spearman disajikan dalam grafik 2 berikut:

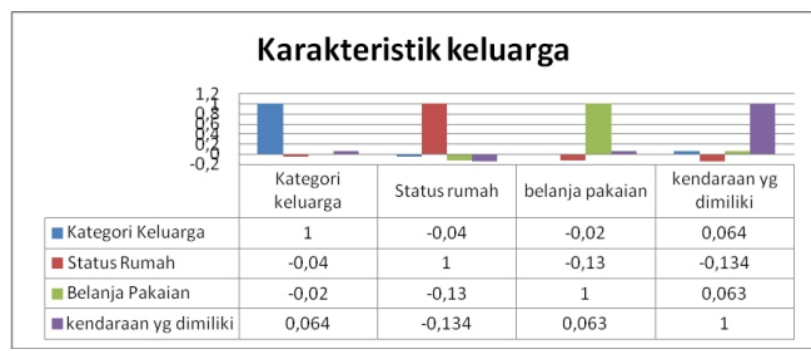

Grafik 2. Karakteristik Keluarga

Berdasarkan Grafik 2, maka dapat dijelaskan bahwa, nilai korelasi kategori keluarga menunjukkan nilai 1,00 , status rumah nilai korelasi $-0,04$, belanja pakaian nilai korelasi $-0,02$, dan kendaraan yang dimiliki nilai korelasi 0,064. Secara hubungan yang signifikan tidak menunjukkan ada hubungan antara variabel tersebut. Artinya dapat dikatakan bahwa variabel karakteristik keluarga tidak menunjukkan korelasi dengan kehidupan yang dilakukan responden.
Komunikasi Keluarga Kepada Anak Balita

Komunikasi keluarga kepada anak Balita meliputi; 1) Sikap keterbukaan pada Balita, 2) Sikap empati pada Balita, 3) Sikap Sportif pada Balita. Untuk menunjukkan nilai Uji Korelasi dengan uji Rank Spearman disajikan dalam grafik 3 berikut:

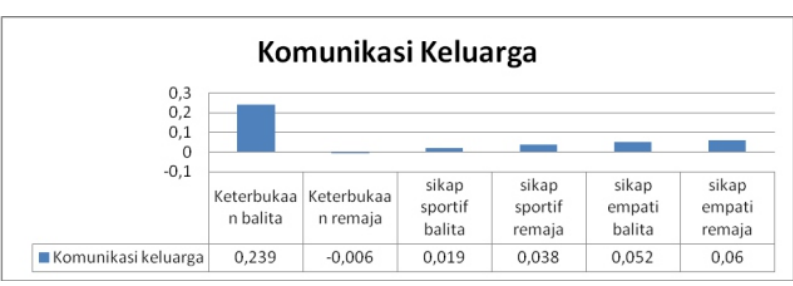

Berdasarkan Grafik 3 diatas, maka dapat dijelaskan bahwa komunikasi keluarga kepada anak balita dan remaja sebagai berikut; nilai korelasi keterbukaan pada balita menunjukkan nilai 0,239, keterbukaan pada remaja nilai korelasi 0,006 , sifat sportif pada balita nilai korelasi 0,019, sikap sportif pada remaja nilai korelasi 0,038. Sikap empati pada balita nilai korelasi 0,052, dan sikap empati pada remaja nilai korelasi 0,06. Secara hubungan yang signifikan menunjukkan ada hubungan antara variabel komunikasi keluarga dengan keterbukaan pada anak balita menunjukkan nilai korelasi yang signifikan 0,239 $(\mathrm{p}<0,05)$. Artinya dapat dikatakan bahwa variabel keterbukaan pada anak balita membuat komunikasi keluarga menjadi lebih baik.

\section{Komunikasi keluarga Kepada anak Remaja}

Komunikasi keluarga kepada anak remaja meliputi;1)Sikap keterbukaan pada remaja, 2) Sikap empati pada remaja, 3) Sikap Sportif pada remaja. Untuk menunjukkan nilai Uji Korelasi dengan Uji Rank Spearman disajikan dalam grafik 4 berikut:

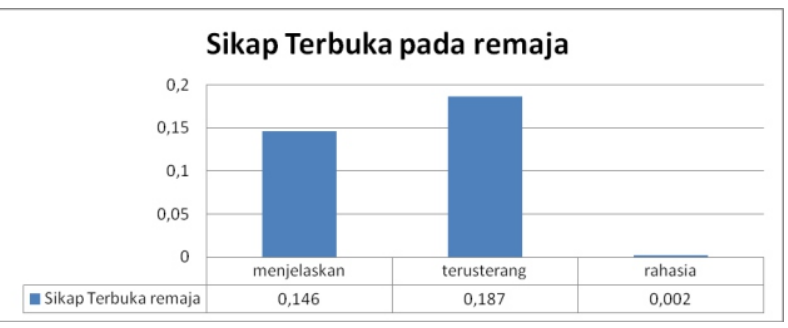

Grafik 4. Sikap Terbuka pada Remaja 
Berdasarkan Grafik 4, maka dapat dijelaskan bahwa sikap terbuka pada remaja sebagai berikut; nilai korelasi menjelaskan 0,146 , nilai korelasi teruterang 0,187 dan nilai korelasi rahasia 0,002. Grafik menunjukkan bahwa ada hubungan sikap keterbukaan orangtua kepada remaja dengan cara menjelaskan yang dilakukan orangtua, begitu juga, sikap terbukaan pada anak remaja berhubungan dengan terusterang yang dilakukan orangtua kepada anak remaja signifikan dalam taraf $\mathrm{p}<0,05$

Sikap empati pada remaja menunjukkan bahwa 147 orang (98\%) menunjukkan baik dalam menunjukkar sikap empati pada anak remajanya. Sikar e mpati dikembangkan dengar memperhatikan remaja dengan masalah yan dihadapi anak remajanya. Orangtua juga memperhatikan aktivitas anaknya, dan marah saat mengetahui anak remajanya memiliki masalah yang lambat diketahui orangtua. Hal yang paling baik dilakukan orangtua adalah selalu memberikan contoh perilaku sopan dalam melakukan sesuatu setiap harinya. Untuk lebih jelasnya di sajikan pada grafik 5 berikut:

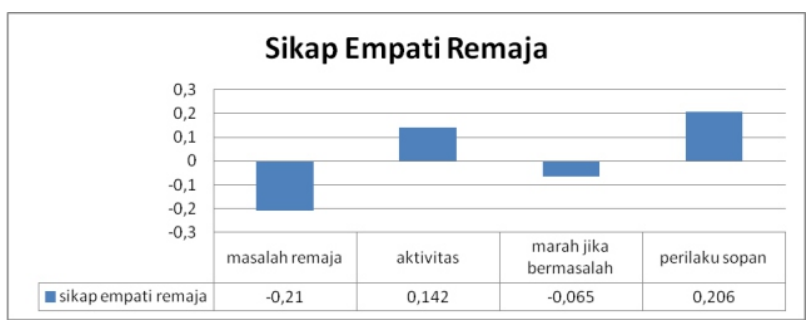

Grafik 4. Sikap Terbuka pada Remaja

Berdasarkan Grafik 5, maka dapat dijelaskan bahwa sikap empati remaja sebagai berikut; nilai korelasi masalah remaja $-0,21$, nilai korelasi aktivitas 0,142 , nilai korelasi marah jika bermasalah -0,065 dan perilaku sopan 0,206. Grafik 6 menunjukkan bahwa ada hubungan sikap empati orangtua kepada anak remaja dengan masalah remaja, nilai korelasi $-0,21$ signifikan dalam taraf $p<0,05$, berarti bahwa jika masalah remaja yang dialami remaja, maka empati juga akan berkurang.

Sikap empati pada remaja juga berhubungan signifikan dengan aktivitas remaja, terlihat nilai korelasi 0,142 $(\mathrm{p}<0,05)$. Juga berhubungan dengan perilaku sopan yang selalu dicontohkan oleh orangtua.
Sikap sportif pada remaja menunjukkan bahwa 142 orang (94,7\%) menunjukkan baik dan bahkan sangat baik dalam menunjukkan sikap sportif pada anak remajanya. Sikap sportif dikembangkan dengan memperhatikan remaja dengan ajarkan untuk mengakui kesalahan, juga diajarkan minta maaf jika remaja melakukan kesalahan.

Serta orangtua juga mengajarkan tanggungjawab. Untuk lebih jelas di sajikan dalam grafik 6 berikut:

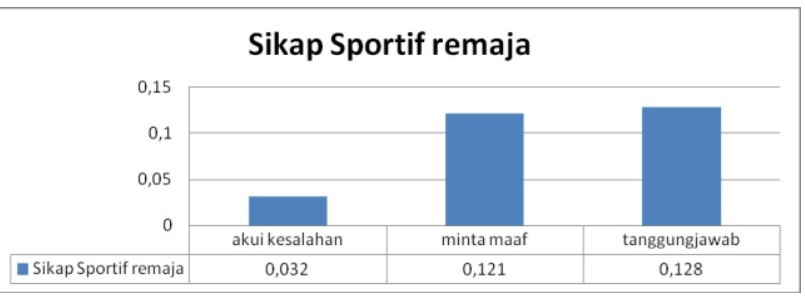

Grafik 4. Sikap Terbuka pada Remaja

Berdasarkan Grafik 6, maka dapat dijelaskan bahwa sikap sportif pada remaja sebagai berikut; nilai korelasi akui kesalahan 0,032, nilai korelasi minta maaf 0,121, nilai korelasi tanggungjawab 0,0128. Grafik menunjukkan bahwa ada hubungan sikap sportif orangtua kepada anak remaja dengan sikap remaja yang minta maaf dan remaja yang memiliki tanggung jawab signifikan dalam taraf $p<0,05$.

\section{Pola pengasuhan Anak Balita}

Pola pengasuhan anak Balita meliputi; 1) Kosistensi mendidik 2) Pengamalan Agama 3) Penerapan Norma 4) Sikap orangtua. Konsistensi mendidik menunjukkan bahwa 145 orang (96,7\%) cukup baik dan baik, 5 orang (3,3\%) tidak baik. Konsistensi yang dilakukan orangtua kepada anak balitanya yaitu membuat kesepakatan dengan anak balita. Orangtua kemudian membuat peraturan yang harus ditaati oleh balitanya. Begitu juga orangtua mencoba konsekuensi menggunakan katakata kepada anak balita. Pengamalan agama menunjukkan bahwa 123 orang $(75,4 \%)$ menunjukkan cukup baik dan kearah baik, 27 orang $(24,6)$ menunjukkan tidak baik. Pengamalan agama dilakukan orangtua kepada anak balita yaitu dengan mencontohkan sholat, menunjukkan perbuatan baik, mencontohkan menolong orang lain. Sikap konsistensi penerapan 
norma kepada balita menunjukkan 85 orang $(56,3 \%)$ cukup baik, dan 65 orang $(43,7 \%)$ baik.

Sikap konsistensi penerapan norma dilakukan orang dengan ajarkan ucapkan kata-kata yang baik, marah jika anak balita tidak berperilaku sopan, orangtua juga mencontohkan perilaku sopan dan santun. Sikap orangtua menunjukkan sikap yang cukup baik dan bahkan cenderung sangat baik kepada anak balitanya, 61 orang $(40,4 \%)$ menunjukkan sikap cukup baik dan 89 orang $(59,6 \%)$ menunjukkan baik dan cenderung sangat baik. Sikap orangtua dalam keluarga kepada anak balita di tunjukkan dengan cara menuntun perilaku anak balita setiap hari, mengarahkan menggunakan mainan, orangtua juga memberikan hadiah sebagai penunjukkan rasa penghargaan kepada anak balita. Berikut ini di tunjukkan dalam grafik 7 berikut:

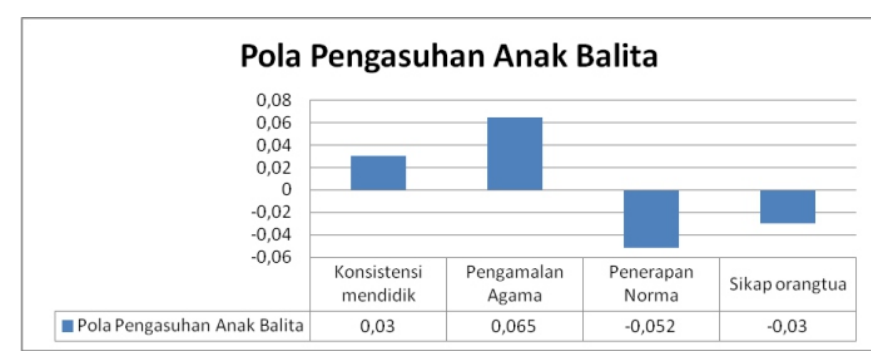

Grafik 7. Pola Pengasuhan Anak Balita

Berdasarkan Grafik 7 diatas, maka dapat dijelaskan bahwa pola pengasuhan anak balita sebagai berikut; nilai korelasi konsistensi mendidik 0,03, nilai korelasi pengamalan agama 0,065, nilai korelasi penerapan Norma -0,052 dan nilai korelasi sikap orangtua $-0,03$. Grafik menunjukkan bahwa tidak ada hubungan secara signifikan semua variabel tersebut dengan pola pengasuhan anak balita.

\section{Pola pengasuhan Anak Remaja}

Pola pengasuhan anak Remaja meliputi; 1) Kosistensi mendidik 2) Pengamalan Agama 3) Penerapan Norma 4) Sikap orangtua. Konsistensi mendidik menunjukkan bahwa 96 orang (64\%) cukup baik dan 54 orang (36\%) baik. Konsistensi yang dilakukan orangtua kepada anak balitanya yaitu membuat kesepakatan dengan remaja dalam aktivitas. Orangtua kemudian membuat peraturan yang harus ditaati oleh remaja.
Begitu juga orangtua mencoba konsekuensi menggunakan kata-kata kepada anak remaja.Pengamalan Agama menunjukkan bahwa 69 orang (46\%) menunjukkan cukup baik dan 81 orang ( $54 \%$ ) kearah baik dan sangat baik. Pengamalan agama dilakukan orangtua kepada anak remaja yaitu dengan marah jika tidak sholat, mencontohkan amalan agama, ajak peduli pada orang susah. Sikap konsistensi penerapan norma kepada balita menunjukkan 143 orang $(93,7 \%)$ cukup baik, baik dan cenderung sangat baik, 7 orang $(4,6 \%)$ tidak baik. Sikap konsistensi penerapan norma dilakukan orangtua marah jika anak remaja ucapkan kata-kata yang tidak baik, ajarakan berperilaku sopan, orangtua juga marah jika tidak duduk dengan baik atau sopan. Sikap orangtua menunjukkan sikap yang cukup baik 41 orang $(27,2 \%)$ menunjukkan sikap cukup baik dan 109 orang $(72,8 \%)$ menunjukkan baik dan cenderung sangat baik. Sikap orangtua dalam keluarga kepada anak remaja dengan cara memberikan petunjuk beribadah, mengarahkan dalam bergaul, orangtua juga memberikan pujian dan hadiah sebagai penunjukkan rasa penghargaan kepada anak remaja. Berikut ini di tunjukkan dalam grafik 8 berikut:

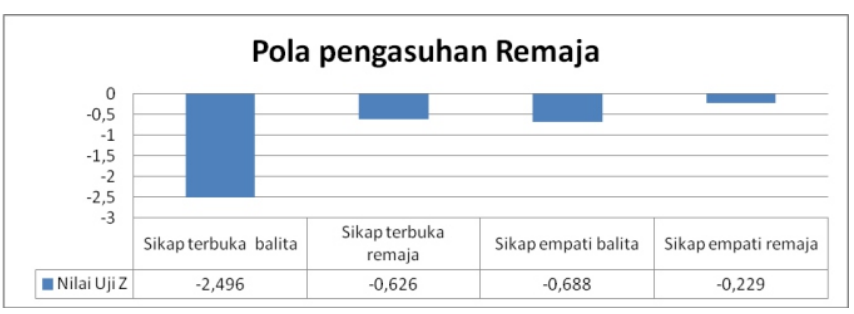

\section{Grafik 8. Pola Pengasuhan Remaja}

Berdasarkan Grafik 8, maka dapat dijelaskan bahwa pola pengasuhan Anak remaja sebagai berikut; nilai korelasi konsistensi mendidik 0,04, nilai korelasi Pengamalan agama 0,22 , nilai korelasi penerapan Norma -0,031 dan nilai korelasi Sikap orangtua 0,016. Grafik 9 menunjukkan bahwa tidak ada hubungan secara signifikan semua variabel tersebut dengan pola pengasuhan anak remaja

\section{Komunikasi Keluarga di Kampung Condet Jakarta Timur}

Komunikasi keluarga yang terjadi di keluarga Betawi di Kampung condet Jakarta Timur meliputi;1) Sikap keterbukaan pada 
Balita 2) sikap keterbukaan pada remaja, 3) sikap empati pada balita, 4) sikap empati pada remaja, 5) sikap sportif pada balita, 6) sikap sportif pada remaja. Untuk lebih lanjut di tuniukkan dalam grafik 9 berikut:

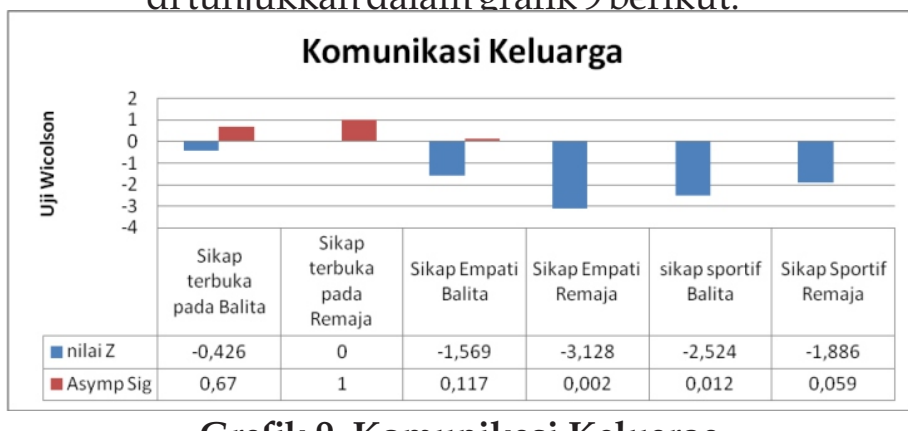

Grafik 9. Komunikasi Keluarga di Kampung Condet

Berdasarkan grafik 9, dapat dikatakan bahwa; sikap keterbukaan pada balita menunjukkan nilai uji z $-0,426$ dengan asymp.sig 0,670, artinya tidak menunjukkan hubungan signifikansi dalam taraf $\mathrm{p}<0,05$ dengan komunikasi keluarga dalam pengasuhan anak balita. Sikap keterbukaan pada remaja nilai uji $z=0$ dengan asymp.sig 1 , artinya juga tidak menunjukkan hubungan signifikasi dalam taraf $\mathrm{p}<0,05$ dengan komunikasi keluarga dalam pengasuhan anak balita. Sikap empati pada balita menunjukkan nilai uji $\mathrm{z}=-1,569$ dengan asymp.sig 0,117. Artinya juga tidak menunjukkan hubungan signifikasi dalam taraf $\mathrm{p}<0,05$ dengan komunikasi keluarga dalam pengasuhan anak balita. Sikap empati pada remaja menunjukkan nilai uji $\mathrm{z}=-3,128$ dengan asymp.sig 0,002, artinya ada hubungan signifikasi dalam taraf $p<0,01$ dengan komunikasi keluarga dalam pengasuhan anak remaja di Kampung Condet Jakarta Timur.

Sikap sportif pada anak Balita menunjukkan nilai uji $\mathrm{z}=-2,524$ dengan asymp.sig 0,012. Artinya ada hubungan signifikansi dalam taraf $\mathrm{p}<0,05$ dengan komunikasi keluarga dalam pengasuhan anak balita di Kampung Condet Jakarta Timur. Sikap sportif pada remaja menunjukkan nilai uji $\mathrm{z}=-1,886$ dengan asymp.sig 0,059. Artinya tidak terlalu nampak hubungan signifikasi dalam taraf $\mathrm{p}<0,05$ dengan komunikasi keluarga dalam pengasuhan anak remaja di Kampung Condet jakarta Timur.

\section{Komunikasi Keluarga di Kampung Tugu Jakarta Utara}

Komunikasi keluarga yang terjadi di keluarga Betawi di Kampung Tugu Jakarta Utara meliputi; 1) Sikap keterbukaan pada Balita 2) sikap keterbukaan pada remaja, 3) sikap empati pada balita, 4) sikap empati pada remaja, 5) sikap sportif pada balita, 6) sikap sportif pada remaja. Untuk lebih lanjut di tunjukkan dalam grafik 10 berikut:

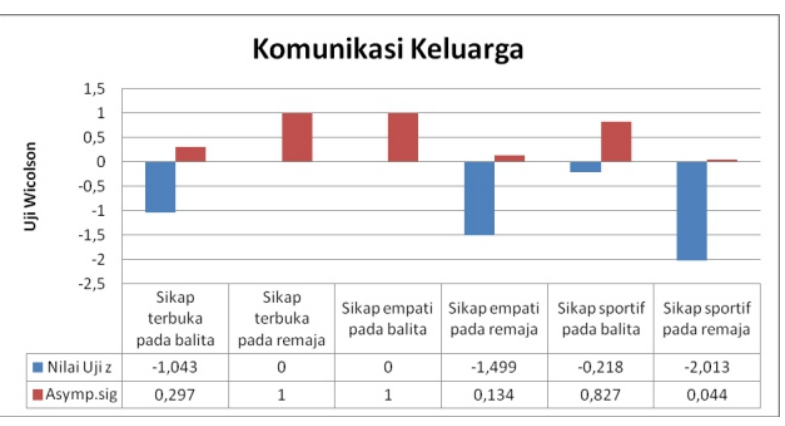

Grafik 10. Komunikasi Keluarga di Kampung Tugu

Berdasarkan grafik 10, dapat dikatakan bahwa; sikap keterbukaan pada balita menunjukkan nilai uji z -1,043 dengan asymp.sig 0,297, artinya tidak menunjukkan hubungan signifikansi dalam taraf $\mathrm{p}<0,05$ dengan komunikasi keluarga dalam pengasuhan anak balita. Sikap keterbukaan pada remaja nilai uji $\mathrm{z}=$ 0,00 dengan asymp.sig 1 , artinya juga tidak menunjukkan hubungan signifikasi dalam taraf $p<0,05$ dengan komunikasi keluarga dalam pengasuhan anak balita. Sikap empati pada balita menunjukkan nilai uji z $=0,00$ dengan asymp.sig 1,00. Artinya juga tidak menunjukkan hubungan signifikasi dalam taraf $\mathrm{p}<0,05$ dengan komunikasi keluarga dalam pengasuhan anak balita. Sikap empati pada remaja menunjukkan nilai uji $\mathrm{z}=-1,499$ dengan asymp.sig 0,134, artinya tidak ada hubungan signifikasi dalam taraf $p<0,01$ dengan komunikasi keluarga dalam pengasuhan anak remaja di Kampung Tugu Jakarta Utara.Sikap sportif pada anak Balita menunjukkan nilai uji $\mathrm{z}=-0,218$ dengan asymp.sig 0,827. Artinya tidak ada hubungan signifikansi dalam taraf $p<0,05$ dengan komunikasi keluarga dalam pengasuhan anak balita di Kampung Tugu Jakarta Utara. Sikap sportif pada remaja menunjukkan nilai uji z $=-2,013$ dengan asymp.sig 0,044. 
Artinya tidak terlalu nampak hubungan signifikasi dalam taraf $\mathrm{p}<0,05$ dengan komunikasi keluarga dalam pengasuhan anak remaja di Kampung Tugu Jakarta Utara.

\section{Komunikasi Keluarga di Kampung Ujung Harapan Bekasi}

Komunikasi keluarga yang terjadi di keluarga Betawi di Kampung Ujung Harapan Bekasi meliputi; 1) Sikap keterbukaan pada Balita 2) sikap keterbukaan pada remaja, 3) sikap empati pada balita, 4) sikap empati pada remaja, 5) sikap sportif pada balita, 6) sikap sportif pada remaja. Untuk lebih lanjut di tunjukkan dalam grafik 11 berikut:

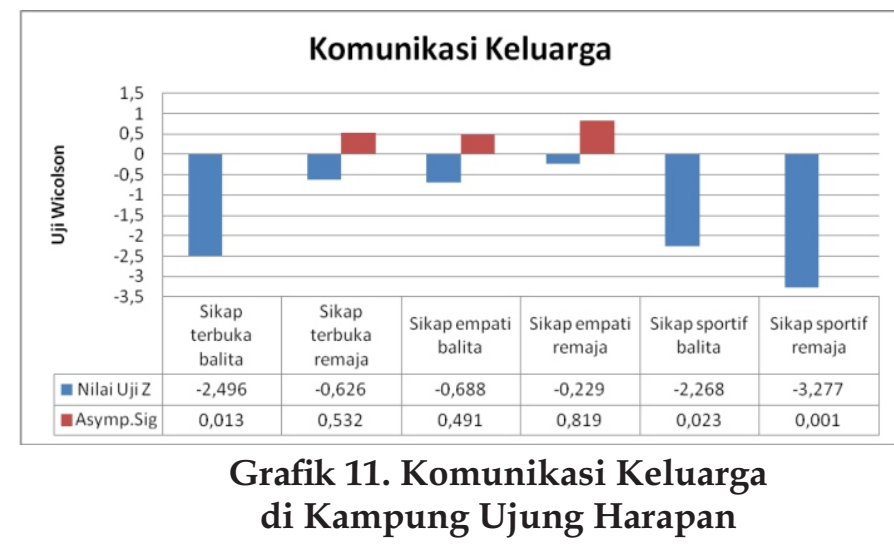

Berdasarkan grafik 11, dapat dikatakan bahwa; sikap keterbukaan pada balita menunjukkan nilai uji z -2,496 dengan asymp.sig 0,013, artinya menunjukkan ada hubungan signifikansi dalam taraf $\mathrm{p}<0,05$ dengan komunikasi keluarga dalam pengasuhan anak balita. Sikap keterbukaan pada remaja nilai uji $\mathrm{z}=$ $-0,626$, dengan asymp.sig 0,532, artinya tidak menunjukkan hubungan signifikasi dalam taraf $\mathrm{p}<0,05$ dengan komunikasi keluarga dalam pengasuhan anak balita. Sikap empati pada balita menunjukkan nilai uji $z=-0,688$ dengan asymp.sig 0,491. Artinya juga tidak menunjukkan hubungan signifikasi dalam taraf $\mathrm{p}<0,05$ dengan komunikasi keluarga dalam pengasuhan anak balita. Sikap empati pada remaja menunjukkan nilai uji $\mathrm{z}=-0,229$ dengan asymp.sig 0,819 , artinya tidak ada hubungan signifikasi dalam taraf $\mathrm{p}<0,05$ dengan komunikasi keluarga dalam pengasuhan anak remaja di Kampung Ujung Harapan Bekasi.
Sikap sportif pada anak Balita menunjukkan nilai uji $\mathrm{z}=-2,268$ dengan asymp.sig 0,023. Artinya tidak ada hubungan signifikansi dalam taraf $p<0,05$ dengan komunikasi keluarga dalam pengasuhan anak balita di Kampung Tugu Jakarta Utara.

Sikap sportif pada remaja menunjukkan nilai uji $\mathrm{z}=-3,277$ dengan asymp.sig 0,001. Artinya ada hubungan signifikasi dalam taraf $\mathrm{p}<0,05$ dengan komunikasi keluarga dalam pengasuhan anak remaja di Kampung Ujung Harapan Bekasi.

Komunikasi Keluarga, Pola Pengasuhan dan Perkembangan Anak di Kampung Tugu Jakarta Utara, Kampung Condet Jakarta Timur dan Kampung Ujung Harapan Bekasi.

Pembahasan hipotesis penelitian bahwa terdapat perbedaan signifikan penggunaan komunikasi keluarga dan pola pengasuhan anak balita dan remaja pada keluarga yang tinggal di Kampung Tugu Jakarta Utara, Kampung Condet Jakarta Timur dan Kampung Ujung Harapan Bekasi." Untuk hal tersebut dilakukan uji Wicolson pada ketiga lokasi penelitian, hasil Uji Z menunjukkan bahwa ada perbedaan secara signifikan penggunaan komunikasi keluarga dan pola pengasuhan anak balita dan remaja pada keluarga di Kampung Tugu Jakarta Utara, Kampung Condet Jakarta Timur dan Kampung Ujung Harapan Bekasi. Untuk lebih jelasnya disajikan pada Tabel 1 berikut: 
Tabel 1. Perbedaan penggunaan komunikasi, pola pengasuhan dan perkembangan anak

\begin{tabular}{|c|c|c|c|c|c|c|c|c|c|}
\hline \multirow[t]{2}{*}{ VARIABEL } & \multicolumn{3}{|c|}{ KAMPUNG CONDET } & \multicolumn{3}{|c|}{ KAMPUNG TUGU } & \multicolumn{3}{|c|}{$\begin{array}{l}\text { KAMPUNG UJUNG } \\
\text { HARAPAN }\end{array}$} \\
\hline & & Uji Z & Sig & & Uji Z & $\mathrm{Sig}$ & & Uji Z & Sig \\
\hline \multirow{3}{*}{$\begin{array}{l}\text { Komunikasi } \\
\text { Keluarga }\end{array}$} & $\begin{array}{l}\text { Sikap } \\
\text { Empati } \\
\text { remaja }\end{array}$ & $-3,128$ & $\begin{array}{c}0,00 \\
2\end{array}$ & \multirow{3}{*}{$\begin{array}{l}\text { Sikap sportif } \\
\text { pada remaja }\end{array}$} & \multirow{3}{*}{$-2,013$} & \multirow{3}{*}{0,044} & $\begin{array}{l}\text { Sikap } \\
\text { terbuka } \\
\text { balita }\end{array}$ & $-2,496$ & 0,013 \\
\hline & \multirow{2}{*}{$\begin{array}{l}\text { Sikap } \\
\text { sportif } \\
\text { balita }\end{array}$} & \multirow{2}{*}{$-2,524$} & \multirow{2}{*}{$\begin{array}{c}0,01 \\
2\end{array}$} & & & & $\begin{array}{l}\text { Sikap } \\
\text { sportif } \\
\text { Balita }\end{array}$ & $-2,268$ & 0,023 \\
\hline & & & & & & & $\begin{array}{l}\text { Sikap } \\
\text { sportif } \\
\text { remaja }\end{array}$ & $-3,277$ & 0,001 \\
\hline \multirow{3}{*}{$\begin{array}{l}\text { Pola } \\
\text { Pengasuhan } \\
\text { Anak }\end{array}$} & $\begin{array}{l}\text { Pengamalan } \\
\text { Agama } \\
\text { Balita }\end{array}$ & $-4,786$ & $\begin{array}{c}0,00 \\
0\end{array}$ & \multirow{3}{*}{$\begin{array}{c}\text { Pengamalan } \\
\text { Agama } \\
\text { Balita }\end{array}$} & \multirow{3}{*}{$-3,029$} & \multirow{3}{*}{0,002} & $\begin{array}{l}\text { Konsiste } \\
\text { nsi } \\
\text { mendidik } \\
\text { Balita }\end{array}$ & $-2,280$ & 0,023 \\
\hline & $\begin{array}{l}\text { Pengamalan } \\
\text { Agama } \\
\text { Remaja }\end{array}$ & $-3,000$ & $\begin{array}{c}0,01 \\
2\end{array}$ & & & & $\begin{array}{l}\text { Pengamal } \\
\text { an } \\
\text { Agama } \\
\text { Balita }\end{array}$ & $-5,058$ & 0,0 \\
\hline & $\begin{array}{l}\text { Penerapan } \\
\text { Norma } \\
\text { remaja }\end{array}$ & $-2,449$ & $\begin{array}{c}0,01 \\
4\end{array}$ & & & & $\begin{array}{l}\text { Penerapa } \\
\text { n Norma } \\
\text { remaja }\end{array}$ & $-2,029$ & 0,042 \\
\hline \multirow{3}{*}{$\begin{array}{l}\text { Perkembangan } \\
\text { Remaja }\end{array}$} & \multirow{3}{*}{$\begin{array}{l}\text { Konsep diri } \\
\text { remaja }\end{array}$} & \multirow{3}{*}{$-3,790$} & \multirow{3}{*}{$\begin{array}{c}0,00 \\
0\end{array}$} & $\begin{array}{c}\text { Perkembang } \\
\text { an Anak } \\
\text { balita }\end{array}$ & $-2,746$ & 0,006 & $\begin{array}{l}\text { Identifika } \\
\text { si diri } \\
\text { balita }\end{array}$ & $-5,557$ & 0,00 \\
\hline & & & & \multirow{2}{*}{$\begin{array}{l}\text { Persepsi diri } \\
\text { remaja }\end{array}$} & \multirow{2}{*}{$-2,999$} & \multirow{2}{*}{0,002} & $\begin{array}{l}\text { Konsep } \\
\text { diri } \\
\text { remaja }\end{array}$ & $-2,456$ & 0,014 \\
\hline & & & & & & & $\begin{array}{l}\text { Persepsi } \\
\text { diri }\end{array}$ & $-2,014$ & 0,041 \\
\hline
\end{tabular}

Berdasarkan Tabel 1, maka dapat dijelaskan bahwa komunikasi keluarga yang dilakukan di Kampung Condet kepada anak balita dan remaja, menunjukkan bahwa sikap empati pada remaja dan sikap sportif pada balita lebih signifikan terhadap perkembangan anak. Sikap empati orangtua kepada anak remaja lebih signifikan dengan nilai uji z -3,128 dengan nilai signifikan 0,002 yang berarti bahwa sikap empati kepada remaja signifikan dala taraf $p<0,01$. Sikap sportif kepada anak Balita menunjukkan nilai uji $\mathrm{Z}$ -2,524 dengan nilai signifikasi 0,012 yang berarti sikap sportif anak balita yang dikembangkan oleh orangtua signifikan dalam taraf $p<0,05$. Sementara Komunikasi Keluarga di Kampung Tugu menunjukkan bahwa sikap sportif pada remaja yang menunjukkan lebih signifikan dengan nilai uji $Z-2,-13$ dan nilai signifikasi 0,044 yang berarti signifikan dalam taraf $p<0,05$. Sedangkan Komunikasi Keluarga di Kampung Ujung Harapan menunjukkan bahwa sikap terbuka pada anak balita, sikap sportif pada anak balita dan sikap sportif pada remaja. Sikap terbuka kepada anak balita menunjukkan nilai uji Z -2,196 dengan nilai signifikasi 0,013 yang berarti signifikasi dalam taraf $p<0,05$. Sikap Sportif kepada anak Balita menunjukkan nilai uji Z -2268 dengan nilai signifikasi 0,023 dalam taraf $p<0,05$. Sikap sportif pada remaja menunjukkan nilai Uji z-3277 dengan nilai signifikansi 0,001 dalam taraf $\mathrm{p}<0,01$.

\section{Simpulan}

Pola komunikasi yang dilakukan keluarga Betawi di Kampung Condet Jakarta Timur menunjukkan bahwa komunikasi lebih mengembangkan sikap e m pati kepada remaja dan mengembangkan sikap sportif kepada anak balita.

Pola komunikasi pada keluarga Betawi di Kampung Tugu menunjukkan bahwa keluarga mengembangkan sikap sportif remaja. Pola komunikasi keluarga pada 
keluarga Betawi di Kampung Ujung Harapan menunjukkan bahwa keluarga mengembangkan sikap terbuka pada anak balita, mengembangkan sikap sportif pada anak balita dan sikap sportif pada remaja.

\section{Daftar Pustaka}

Arikunto S. (2006). Prosedur Penelitian Suatu Pendekatan Praktek, Edisi Revisi keenam. Yogyakarta: Rineka Cipta.

Crain. (2007). Teori perkembangan anak, konsep dan aplikasi, Edisi ke Tiga, Yogyakarta: Pustaka Pelajar.

Creswell J. W. (2002). Research design, desain penelitian qualitative and quantitative approaches. Jakarta: KIK Press.

DeVito, Joseph. (2007). The Interpersonal Communication Book Elevent Edition. USA: Pearson Education.

Gunarsa, S.D \& Gunarsa, Y.S. (2004). Psikologi Praktis: Anak. Remaja. Dan Keluarga. Jakarta: PT BPK Gunung Mulia.

Hastuti, D. (2008). Pengasuhan: Teori dan Prinsip serta Aplikasinya di Indonesia. Bogor (ID): Departemen Ilmu Keluarga dan Konsumen. Fakultas Ekologi Manusia IPB.

Irmawati, (2004), Motivasi Berprestasi dan Pola Pengasuhan Pada Suku Bangsa Batak Toba Di Desa Parpareran II Tapanuli Utara; Makalah Seminar Temu Ilmiah Nasional \& Kongres IX Himpunan Psikologi Indonesia Surabaya, 15-17 Januari 2004.

Supriatna, (2008), Kepercayaan Tradisional dan Ketakwaan Terhadap Tuhan yang Maha Esa dalam Sistem Sosial Budaya Masyarakat Betawi di DKI Jakarta, Jurnal Penelitian Vol.40 No.1 April 2008;607640. 